\title{
Effect of Bone Proteins on Human Prostate Cancer Cell Lines In Vitro
}

\author{
Thomas G. Hullinger, ${ }^{* *}$ Laurie K. McCauley, ${ }^{2}$ Melanie L. DeJoode, ${ }^{2}$ and \\ Martha J. Somerman ${ }^{1,2}$ \\ 'Department of Pharmacology, School of Medicine, University of Michigan, \\ Ann Arbor, Michigan \\ ${ }^{2}$ Department of Periodontics/Prevention/Geriatrics, School of Dentistry, University of \\ Michigan, Ann Arbor, Michigan
}

\begin{abstract}
BACKGROUND. Despite the high incidence and serious consequences of skeletal metastasis in prostate cancer patients, the mechanisms involved in establishing secondary lesions in bone are not well-understood. In this study, the role of the mineralized bone matrix in the process of skeletal metastasis was evaluated.

METHODS. Attachment, migration, and proliferation responses of human prostate cancer cells to a crude bone protein extract (CBE) were studied. LNCaP and DU145 cells were utilized in 24-hr attachment assays. Boyden chamber chemotactic assays and cell proliferation assays utilized DU145 cells.

RESULTS. CBE and fibronectin (FN) promoted attachment of DU145 cells, whereas only FN facilitated attachment of LNCaP cells. CBE-mediated adhesion of DU145 cells was reduced by $94 \%$ with cycloheximide, by $98 \%$ with RGD peptides, and by $94 \%$ with an antibody to $\alpha \mathrm{v} \beta 3$. Although DU145 cells migrated toward FN, CBE did not promote migration of DU145 cells. DU145 cells grown in the presence of CBE-containing media demonstrated a significant reduction in cell number by day 4 . The antiproliferative effect of CBE was not due to cell toxicity.

CONCLUSIONS. In conclusion, results from this study indicate that mineralized bone proteins promote the attachment of DU145 cells in vitro and suggest that bone proteins may play a key role in vivo during the development of metastatic prostate lesions in bone. Prostate 36:14-22, 1998. (c) 1998 Wiley-Liss, Inc.
\end{abstract}

KEY WORDS: $\quad$ skeletal metastasis; adhesion; integrins; proliferation; chemotaxis

\section{INTRODUCTION}

The incidence of and mortality from prostate cancer are increasing yearly in the United States, with an estimated 224,000 new cases and 40,000 deaths attributed to the disease in 1995 [1]. A significant event contributing to morbidity and mortality associated with prostate cancer is the development of skeletal metastasis. Epidemiological data indicate that $70 \%$ of prostate cancer patients develop secondary metastatic lesions in bone [2]. An effective therapy for the treatment of skeletal metastases has yet to be developed, in part due to an incomplete understanding of the precise mechanisms involved in the development of secondary tumors in bone.
Several cells located in bone have been implicated in the pathogenesis of skeletal metastasis in prostate cancer. Haq et al. [3] reported that bone marrowderived endothelial cells support preferential attachment of rat prostate cancer cells in vitro, suggesting that bone marrow sinusoidal capillaries play an active role in recruitment of prostate cancer cells to bone.

Contract grant sponsor: SPORE; Contract grant number: P50-CA69568.

${ }^{*}$ Correspondence to: Thomas G. Hullinger, Department of Periodontics/Prevention/Geriatrics, School of Dentistry, University of Michigan, 1011 N. University Ave., Ann Arbor, MI 48109-1078. Email: tghullin@umich.edu

Received 10 July 1997; Accepted 24 February 1998 
Utilizing a mouse coinoculation model, Gleave et al. [4] showed that bone fibroblasts enhance the growth of human prostate cancer cells in vivo, suggesting that bone stromal cells may also play a role in skeletal metastases. Osteoblasts, being a rich source of growth factors, have also been implicated as a cell type involved in the pathogenesis of skeletal metastases by promoting growth [5] and attachment [3] of prostate cancer cells. Importantly, factors secreted by osteoblasts as well as circulating factors are entrapped in bone and provide a rich source of growth factors to facilitate the proliferation of tumor cells in the bone microenvironment. For example, insulin-like growth factor I (IGF-I), found in high concentrations in bone, stimulates DNA synthesis in [6,7], and migration of [7], human prostate cancer cells in vitro. Thus, bone provides an environment with the potential to attract and subsequently promote the growth of prostate cells.

Although a variety of mechanisms have been proposed to be involved in the development of bone metastases, the role of the mineralized bone matrix has not been determined. Recent results by Ritchie et al. [7] indicate that when bone-derived factors are evaluated individually, they have variable effects on migration and proliferation of several human prostate cancer cell lines in vitro, including DU145 cells. For example, IGF-I and IGF-II enhanced prostate cancer cell proliferation, whereas TGF $\beta$ induced a biphasic proliferative response. In order to investigate a potentially more pathophysiologic situation, a crude mixture of endogenous proteins extracted from bone was utilized in the present study. In addition to growth factors, it is well-established that bone is a rich source for several other molecules. These additional molecules include chemotactic and attachment factors such as fibronectin (FN), collagen, bone salioprotein (BSP), and osteopontin (OPN) [8]. The use of crude bone protein extract (CBE) in this study allowed us to assess the net effect of the many proteins present in bone on several key events in the pathogenesis of prostate cancer metastasis to bone.

We hypothesized that proteins contained within the mineralized bone matrix would stimulate prostate cancer cells to exhibit responses crucial to establishing secondary lesions. These critical responses were tumor cell migration, attachment, and proliferation. To test this hypothesis, the ability of CBE to promote the attachment of an androgen-dependent human prostate cancer cell line (LNCaP cells) and an androgenindependent human prostate cancer cell line (DU145 cells) was evaluated. Results demonstrated a 5-10-fold increase in CBE-mediated attachment of DU145 cells when compared to CBE-mediated attachment of LNCaP cells. Given that DU145 cells demonstrated the stronger response to bone proteins, DU145 cells were selected for further evaluation of the effects of crude bone extracts (CBE) on adhesion, migration, and proliferation of prostate cancer cells. Results indicate that crude protein extracts of bone promote attachment of DU145 cells in vitro, and suggest that proteins within bone may influence prostate cancer cell behavior in vivo.

\section{MATERIALS AND METHODS}

\section{Cell Culture}

DU145 cells were originally isolated from a human prostate adenocarcinoma patient in 1976 [9]. Extensive tumor metastasis to the vertebral column and right femoral neck was observed in this patient. Additional metastases to lymph nodes, liver, lungs, and brain were also noted. The DU145 cell line was established from a central nervous system lesion. Importantly, no additional primary carcinomas were found. DU145 cells were provided by Dr. Ken Pienta (SPORE in Prostate Cancer at the University of Michigan). DU145 cells were maintained in Dulbecco's modified Eagle's medium (DMEM/F12), 10\% FBS, 100 units $/ \mathrm{ml}$ penicillin, and $100 \mu \mathrm{g} / \mathrm{ml}$ streptomycin (all culture reagents from GIBCO/BRL Life Technologies, Inc., Grand Island, NY). Cells were not used beyond passage 50. Experiments were conducted with DU145 cells at $70-80 \%$ confluency.

LNCaP cells were originally isolated from a human prostate adenocarcinoma patient in 1977 [10]. Disseminated bony metastases were found on bone scan, with metastases to lymph nodes also noted. The LNCaP cell line was established from a supraclavicular lymph node lesion. LNCaP cells were obtained from UroCor, Inc. (Oklahoma City, OK) and maintained in T-medium containing 5\% FBS, 100 units $/ \mathrm{ml}$ penicillin, and $100 \mu \mathrm{g} / \mathrm{ml}$ streptomycin, as recommended by UroCor. Experiments were conducted with $\mathrm{LNCaP}$ cells at $70-80 \%$ confluency.

\section{Preparation of Crude Bone Extracts (CBE)}

The procedure outlined here has been previously described in detail [11,12]. Briefly, bone fragments from bovine femurs were washed for 2 days with phosphate-buffered saline containing protease inhibitors $\left(\mathrm{pH} 7.4,4^{\circ} \mathrm{C}\right)$. Bone proteins were extracted with 4 $\mathrm{M}$ guanidine-HCL at $4^{\circ} \mathrm{C}$ for 7 days, followed by $4 \mathrm{M}$ guanidine-HCL/ethylenediaminetetraacetic acid (EDTA) at $4^{\circ} \mathrm{C}$ for 7 days. Both guanidine extractions were performed in the presence of protease inhibitors (0.05 M 6-aminohexanoic acid, $0.005 \mathrm{M}$ benzamidine $\mathrm{HCL}$, and $0.001 \mathrm{M}$ phenylmethylsufonyl fluoride), 
previously demonstrated to prevent protein degradation during extraction procedures [12]. Extracts were then gravity-filtered and concentrated by ultrafiltration under pressure. Concentrated extracts were dialyzed against distilled water and lyophilized. Samples were stored at $-20^{\circ} \mathrm{C}$. Studies utilized $4 \mathrm{M}$ guanidineHCL/EDTA extracts, containing proteins bound to the mineral phase.

\section{RNA Extraction and Northern Blot Analysis}

Total RNA was extracted from DU145 cells at 80\% confluency, using a modified guanidinium isothiocyanate procedure [13]. Total RNA $(20 \mu \mathrm{g})$ was separated electrophoretically in a $1 \%$ agarose- $5 \%$ formaldehyde gel. RNA was then transferred to a Duralon-UV membrane (Stratagene, La Jolla, CA) and immobilized by UV crosslinking. Membranes were hybridized overnight at $42^{\circ} \mathrm{C}$ with $32 \mathrm{P}$ cDNA probes for human $\alpha \mathrm{V}$ and $\beta 3$ integrin subunits (cDNAs kindly provided by Dr. Gideon Rodan, Merck and Company Inc., West Point, PA). After a wash at high stringency, the blots were exposed to XOMAT film (Eastman Kodak Co., Rochester, NY) for 5 days at $-70^{\circ} \mathrm{C}$.

\section{Cell Adhesion Assay}

Twenty-four-well Falcon plastic plates (Becton Dickinson, Lincoln Park, NJ) were precoated with 400 $\mu l$ of the putative attachment agent at the following concentrations: fibronectin (FN) $20 \mu \mathrm{g} / \mathrm{ml}$ (Sigma Chemical Co., St. Louis, MO), CBE $20 \mu \mathrm{g} / \mathrm{ml}$ and 50 $\mu \mathrm{g} / \mathrm{ml}$, or water as a negative control. Tissue culture plates served as a positive control. After coatings had dried, the dishes were preincubated with serum-free DMEM/F12 containing $0.1 \%$ bovine serum albumin (BSA) for $1 \mathrm{hr}$ at $37^{\circ} \mathrm{C}$. Following the preincubation period, 20,000-30,000 cells were added to the wells, and attachment was evaluated at 4 and $24 \mathrm{hr}$. Unattached cells were removed by rinsing the wells twice with Hank's balanced salt solution. Cells were visualized for extent of cell spreading, and photos were taken. Attached cells were removed with trypsin/ EDTA, and any cell aggregates were gently agitated with a pipette until these aggregates were no longer observed under the microscope. Individual cells were then quantitated with a Coulter counter (Coulter Corporation, Miami, FL). The mechanism(s) of bone extract and fibronectin-mediated cell adhesion were evaluated with the addition of one of the following during the preincubation period: cycloheximide (10 $\mu \mathrm{g} / \mathrm{ml}$, Sigma Chemical Co.), arginine-glycineaspartic acid (RGD) or arginine-glycine-glutamic acid (RGE) peptides $(100 \mu \mathrm{g} / \mathrm{ml}$, University of Michigan Biomedical Research Core Facilities), murine mono- clonal antibody to $\alpha \mathrm{v} \beta 3$ (LM609) (100 $\mu \mathrm{g} / \mathrm{ml}$, provided by David E. Cheresh, The Scripps Research Institute La Jolla, CA), rabbit monoclonal antibody to human FN (100 $\mu \mathrm{g} / \mathrm{ml}$, GIBCO), mouse IgG (100 $\mu \mathrm{g} /$ $\mathrm{ml}$, Sigma Chemical Co.), and rabbit IgG $(100 \mu \mathrm{g} / \mathrm{ml}$, Sigma Chemical Co.). Dose selection for each reagent was based on previous studies [14,15]. All attachment conditions were evaluated in triplicate, and experiments were conducted on at least three separate occasions.

\section{Cell Migration Assay}

A Boyden chamber chemotactic assay [16] was utilized in which the lower chamber contained the putative chemotactic agent dissolved in serum-free DMEM/F12/0.1\% BSA media at the following concentrations: CBE at 20 and $50 \mu \mathrm{g} / \mathrm{ml}$, osteopontin fusion protein (GST-OPN) at 20 and $50 \mu \mathrm{g} / \mathrm{ml}$, and FN at $20 \mu \mathrm{g} / \mathrm{ml}$. (GST-OPN was prepared using the method of Xuan et al. [14]). Nuclepore polycarbonate membranes (Costar Corporation, Cambridge, MA) with $8.0-\mu \mathrm{m}$ diameter pores were precoated with a solution containing $0.002 \%$ swine gelatin and $0.5 \%$ acetic acid for $1 \mathrm{hr}$ at $90^{\circ} \mathrm{C}$ and allowed to dry overnight. The membranes were then placed between the lower and upper chambers. Subconfluent cells $(20,000-25,000)$ were added to the upper chamber in serum-free DMEM/F12/0.1\% BSA media. Chemotactic activity was evaluated at 3, 6, and $24 \mathrm{hr}$. Membranes were removed, fixed in methanol, and stained with hematoxylin and eosin. The upper surface of the membrane was gently swabbed to remove cells which had not migrated through the membrane. Migrated cells were then counted in five nonoverlapping fields per membrane with light microscopy (100x magnification) and averaged. All chemotactic conditions were evaluated in triplicate. Chemotaxis experiments were conducted on three separate occasions.

\section{Proliferation Assay}

DU145 cells were seeded at 5,000 cells/well in 24well tissue culture dishes and grown overnight in 10\% FBS DMEM/F12 media. Media were removed the next day and the wells were washed with phosphatebuffered saline (PBS), to remove any unattached cells. Next, on day 0, the cells were incubated in DMEM/ F12 under the following conditions, in triplicate: 10\% FBS, $2 \%$ FBS, or $2 \%$ FBS plus CBE $(20 \mu \mathrm{g} / \mathrm{ml})$. Media were changed on day 2. Proliferation was assessed on days 1,2, and 4 by removing the media and rinsing the wells twice with Hank's balanced salt solution to remove the unattached cells. Attached cells were removed with trypsin/EDTA, and any cell aggregates were gently agitated with a pipette until these aggre- 


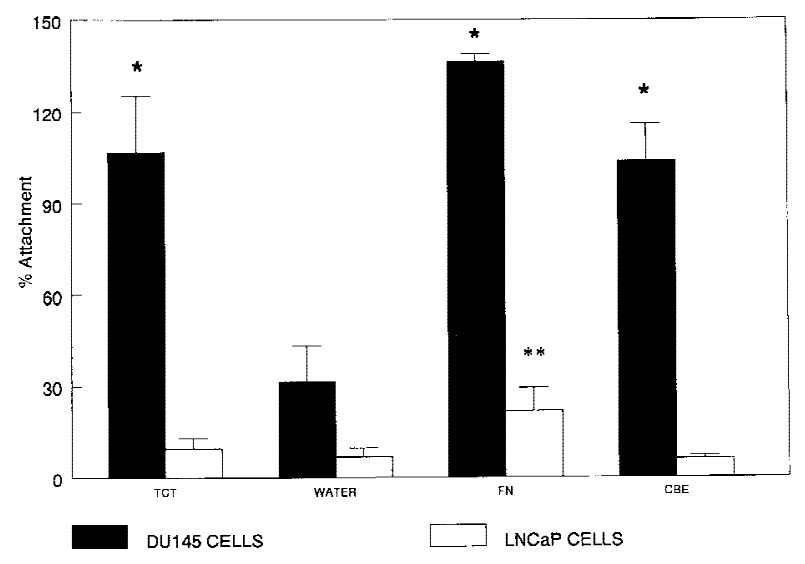

Fig. I. CBE-mediated attachment of LNCaP and DUI45 cells. Cells were plated on tissue culture plates (TCT) or plastic plates precoated with one of the following: water, $20 \mu \mathrm{g} / \mathrm{ml}$ fibronectin (FN), or $20 \mu \mathrm{g} / \mathrm{ml}$ crude bone extract (CBE). After $24 \mathrm{hr}$, unattached cells were removed and attached cells were quantitated with a Coulter counter. Data are expressed as mean \pm SD of triplicate plates. CBE promoted attachment of DUI45 cells $(* P<0.005)$. FN promoted attachment of LNCaP cells $(* * P<0.05)$, while CBE did not. LNCaP cells demonstrated a lower level of attachment in each condition evaluated when compared to DUI 45 cells.

gates were no longer observed under the microscope. Individual cells were then quantitated with a Coulter counter. Proliferation experiments were conducted on three separate occasions.

\section{Statistics}

The unpaired $t$-test (two-tailed; $P<0.05$ ) was employed to compare mean experimental values with the corresponding control values.

\section{RESULTS}

\section{Effect of CBE on DUI45 and LNCaP Cell Adhesion}

Twenty-four-hour attachment results demonstrated that CBE promoted attachment of DU145 cells $(P<0.005)$ when compared to water-coated controls (Fig. 1). Although fibronectin promoted attachment of LNCaP cells $(P<0.05), \mathrm{CBE}$ did not facilitate attachment of LNCaP cells. Furthermore, attachment results indicated that, under all conditions evaluated, the percent attachment of LNCaP cells was substantially lower than percent attachment of DU145 cells. Given that DU145 cells demonstrated a stronger attachment profile and that $\mathrm{CBE}$ promoted attachment of these cells, CBE-facilitated adhesion, migration and proliferation were further characterized utilizing DU145 cells only.

Morphologic observations $4 \mathrm{hr}$ following plating of
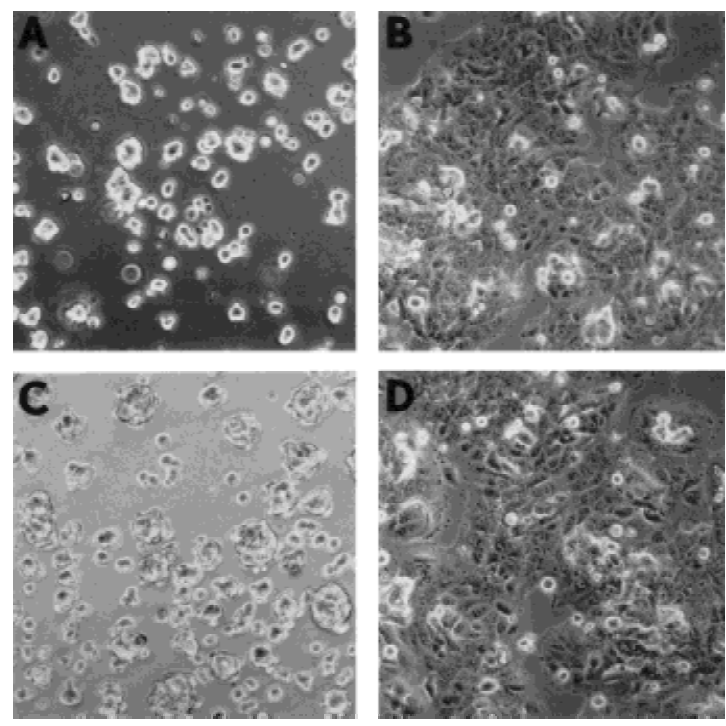

Fig. 2. Phase-contrast light photomicrographs demonstrating DUI45 cell morphology, following 24-hr incubation on CBEcoated plates. A: DUI45 cells incubated on plastic plates precoated with water remained rounded and unattached. B: DUI45 cells incubated with $20 \mu \mathrm{g} / \mathrm{ml}$ crude bone extract adhered and spread on the plates. Attachment morphology was also evaluated with the addition of RGD (C) or RGE (D) peptides ( $100 \mu \mathrm{g} / \mathrm{ml})$ to the preincubation media. RGD peptides blocked CBE-mediated attachment and spreading, while cells incubated in the presence of RGE peptides attached and spread on CBE coated plates (I00x).

DU145 cells suggested that aggregation of cells occurred in water-coated and CBE-coated wells, with weak attachment of these aggregates in the CBEcoated wells (minimal cell spreading on the plates was observed). In contrast, cells exposed to fibronectin were uniformly dispersed in wells, with no evidence of cell aggregation at $4 \mathrm{hr}$. In addition, cells demonstrated a greater extent of spreading on fibronectincoated dishes when compared with cells on control or CBE-coated wells at $4 \mathrm{hr}$. Morphologic evaluation of cells at $24 \mathrm{hr}$ demonstrated that the cell aggregates on CBE-coated wells had established a firmly attached/ spread morphology, while cells on uncoated dishes failed to exhibit properties of cell attachment/ spreading (Fig. 2). Attachment of cells in dishes coated with CBE at $20 \mu \mathrm{g} / \mathrm{ml}$ was similar to that at $50 \mu \mathrm{g} / \mathrm{ml}$ (data not shown). Cells grown on FN-coated dishes for $24 \mathrm{hr}$ maintained the uniform dispersion pattern observed at $4 \mathrm{hr}$ and were firmly attached to the dishes.

To further characterize the dynamics of DU145 cell adhesion on CBE-coated dishes, the role of protein synthesis in this process was assessed. The addition of cycloheximide to the preincubation media significantly reduced adhesion of DU145 cells to all substrates examined (Fig. 3), including CBE, which demonstrated a $94 \%$ reduction in attachment, indicating that cell adhesion to $\mathrm{CBE}$ requires protein synthesis. 


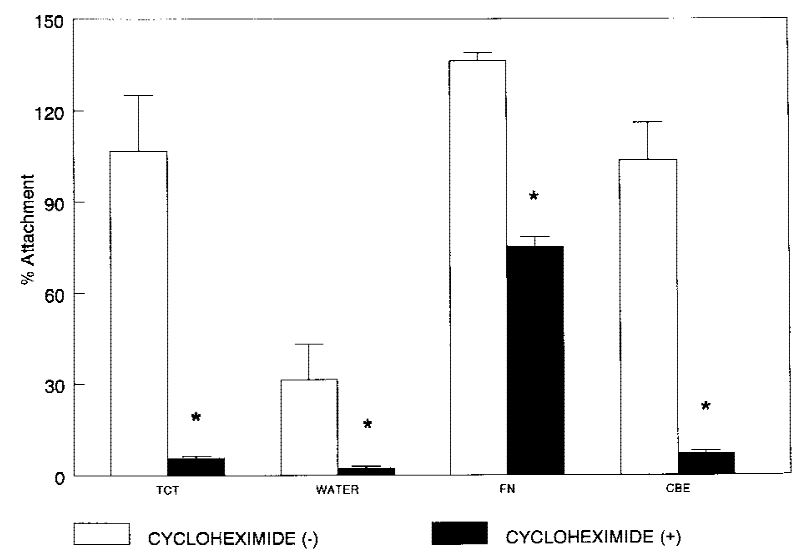

Fig. 3. Effect of protein synthesis inhibition on DUI45 cell attachment. DUI45 cells were incubated on tissue culture plates (TCT) or plastic plates precoated with one of the following: water, $20 \mu \mathrm{g} / \mathrm{ml}$ fibronectin (FN), or $20 \mu \mathrm{g} / \mathrm{ml}$ crude bone extract (CBE). Attachment conditions were duplicated with the addition of cycloheximide $(10 \mu \mathrm{g} / \mathrm{ml})$ to the preincubation media. After $24 \mathrm{hr}$, unattached cells were discarded, and attached cells were quantitated with a Coulter counter. Data are expressed as mean \pm SD of triplicate plates (*P $<0.05$ vs. no cycloheximide).

Cycloheximide also significantly reduced attachment of DU145 cells to fibronectin; however, protein synthesis inhibition was less effective, with only a $45 \%$ reduction in cell attachment observed. Cell adhesion to CBE was RGD-dependent (Fig. 4), as the addition of RGD peptides reduced cell adhesion to CBE coated dishes by $98 \%$. The control RGE peptides did not significantly alter cell adhesion. RGD peptides also significantly reduced cell attachment to FN-coated dishes; however, as with the cyloheximide treatment, RGD blockade was less effective in FN-coated wells, as indicated by only a $27 \%$ reduction in attachment. In addition, cell adhesion to CBE-coated dishes was nearly abolished by the monoclonal antibody to $\alpha \mathrm{v} \beta 3$ (LM609), with a 94\% reduction observed. An antibody to FN completely blocked FN-mediated attachment of DU145 cells (98\% reduction), while reducing CBEmediated attachment by only $38 \%$ (Fig. 5). No effect on CBE-mediated cell attachment was observed with mouse or rabbit IgG control antibodies (data not shown).

\section{DUI45 Cell Chemotaxis}

To determine the chemotactic response of DU145 cells to CBE, a Boyden chamber system was utilized. $\mathrm{CBE}$ at both $20 \mu \mathrm{g} / \mathrm{ml}$ and $50 \mu \mathrm{g} / \mathrm{ml}$ did not promote migration of DU145 cells (Fig. 6). Significant increases in directed migration of DU145 cells were observed in response to $20 \mu \mathrm{g} / \mathrm{ml} \mathrm{FN}$.

Next, since the antibody to $\alpha \mathrm{v} \beta 3$ blocked CBEmediated attachment of DU145 cells, these cells were

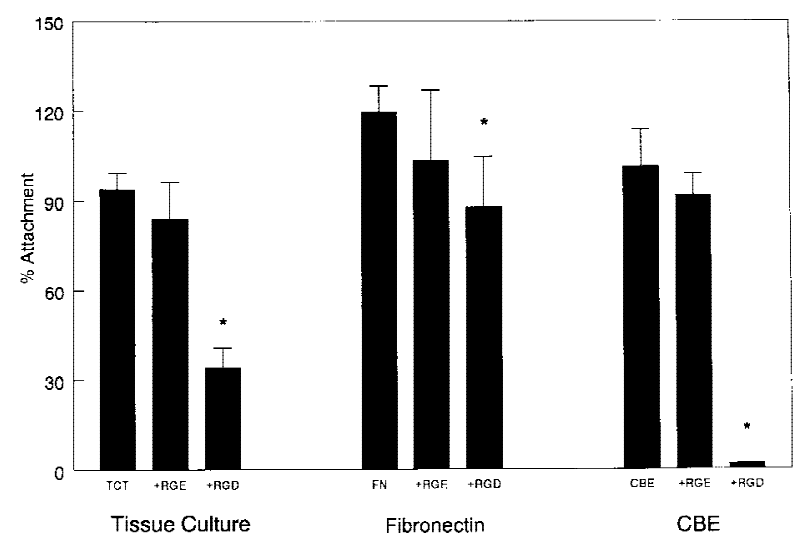

Fig. 4. Effects of RGD and RGE peptides on CBE-mediated attachment of DUI45 cells. DUI45 cells were plated on tissue culture plates (TCT) or plastic plates precoated with $20 \mu \mathrm{g} / \mathrm{ml}$ fibronectin (FN) or $20 \mu \mathrm{g} / \mathrm{ml}$ crude bone extract (CBE). Cell attachment was further evaluated with the addition of RGD or RGE peptides $(100 \mu \mathrm{g} / \mathrm{ml})$ to the preincubation media. After $24 \mathrm{hr}$, unattached cells were removed and attached cells were quantitated with a Coulter counter. RGD peptides abolished cell attachment to CBE-coated plates. Data are expressed as mean \pm SD of triplicate plates $(* P<0.05$ vs. respective control [no RGD or RGE peptides]).

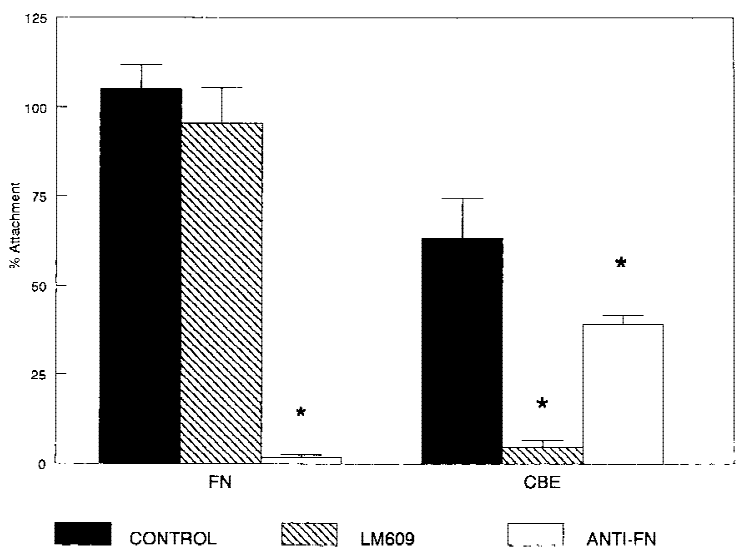

Fig. 5. Effect of antibodies directed against fibronectin or $\alpha v \beta 3$ on CBE-mediated attachment of DUI45 cells. DUI45 cells were plated on tissue culture plates (TCT) or plastic plates precoated with $20 \mu \mathrm{g} / \mathrm{ml}$ fibronectin (FN) or $20 \mu \mathrm{g} / \mathrm{ml}$ crude bone extract (CBE). Attached cells were quantitated after $24 \mathrm{hr}$ with a Coulter counter. CBE-mediated attachment was further characterized with the addition to the preincubation media of an antibody to $\alpha v \beta 3$ (LM609), which blocked CBE-mediated attachment, or an antibody to fibronectin $(100 \mu \mathrm{g} / \mathrm{ml})$ which was less effective at blocking CBE-mediated attachment of DUI 45 cells. Note that the antibody to fibronectin blocked FN-mediated attachment. Data expressed as mean \pm SD of triplicate plates ( $* P<0.05$ vs. control).

evaluated for expression of mRNAs for $\alpha \mathrm{v}$ and $\beta 3$. As seen in Figure 7, DU145 cells expressed mRNAs for $\alpha \mathrm{v}$ and $\beta 3$. Given that OPN, a known ligand for $\alpha v \beta 3$, is present in CBE [11], and that OPN promotes cell migration [17], we evaluated the ability of OPN to pro- 
Fig. 6. Effects of CBE and GST-OPN on DUI45 cell migration. DUI45 cell migration (chemotactic activity) was evaluated with a Boyden chamber assay. Migration toward FN $(20 \mu \mathrm{g} / \mathrm{ml})$, and CBE or GST-OPN at 20 and $50 \mu \mathrm{g} / \mathrm{ml}$, was evaluated at 3,6 , and $24 \mathrm{hr}$ by removing the membrane between the chambers and gently swabbing the upper surface to remove cells which had not migrated through the pores in the membrane. Migrated cells were quantitated with light microscopy in five nonoverlapping fields per membrane. Data are expressed as mean fold increase from control \pm SEM of triplicate plates. CBE and GST-OPN did not promote DUI45 cell migration. However, FN did promote migration of DUI45 cells ( $* P<0.005$, comparison of the mean migrated cell number between experimental and control conditions [absence of putative chemotactic agent]).

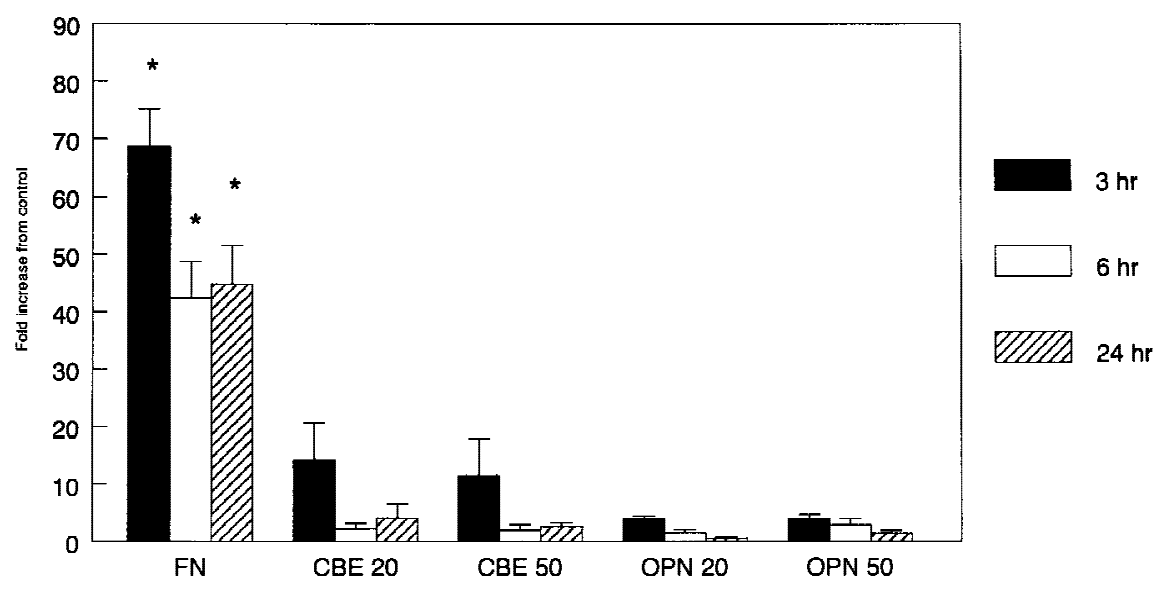

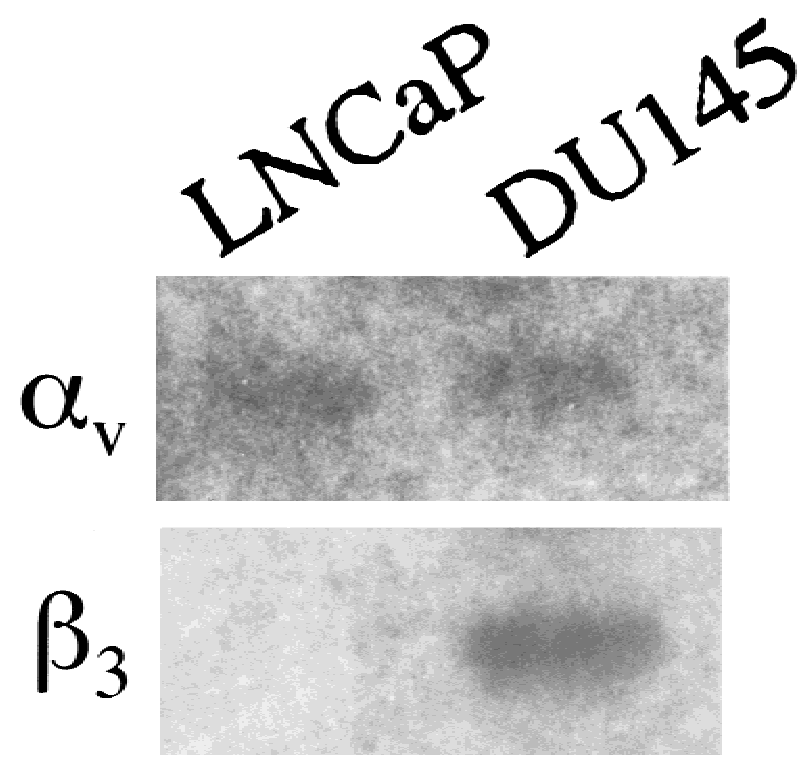

Fig. 7. Expression of $\alpha v$ and $\beta 3$ integrin subunit mRNAs in DUI45 and LNCaP cells. Total RNA ( $20 \mu \mathrm{g} / \mathrm{lane})$ was analyzed by Northern hybridization to 32P-labeled $\alpha v$ and $\beta 3$ probes. Note that both cell lines express $\alpha v$ mRNA, while only DUI45 cells express mRNA for the $\beta 3$ subunit.

mote migration of DU145 cells. As with CBE, no significant increase in directed migration of DU145 cells was observed in response to osteopontin (Fig. 6).

\section{Effect of CBE on DUI45 Cell Proliferation}

To evaluate the mitogenic potential of $\mathrm{CBE}$ on DU145 cells, a 4-day cell proliferation assay was utilized in which DU145 cell proliferation was deter- mined by changes in cell number. As demonstrated in Table I, media containing $2 \%$ serum significantly reduced cell number on day 4 when compared to cells grown in media containing $10 \%$ serum. To determine the effect of CBE, cells were grown in media containing $2 \%$ serum plus CBE at $20 \mu \mathrm{g} / \mathrm{ml}$. The data demonstrate that bone proteins inhibited DU145 cell proliferation on day 4 (Table I). The number of DU145 cells present in the CBE-containing media was reduced by $28 \%$ on day 4 when compared to the number of cells present in the media containing $2 \%$ serum alone. This reduction was statistically significant $(P<0.05)$. No significant differences in DU145 cell proliferation were noted between treatment groups at early time points, i.e., on days 1 or 2 . To investigate the possibility that $\mathrm{CBE}$ was toxic to the cells, trypan blue exclusion was evaluated on day 4 , with $>99 \%$ exclusion of the dye in all treatment groups, indicating that the antiproliferative effect of CBE was not due to cell toxicity (data not shown).

\section{DISCUSSION}

Results from this study suggest that proteins located in the mineralized compartment of bone facilitate adhesion of tumor cells and thus may play an important role in the pathogenesis of bone metastases in prostate cancer. LNCaP cells demonstrated a low level of attachment under all conditions evaluated when compared to DU145 cells. Thus, the DU145 cell line was utilized for further study.

The bone protein extract utilized in this study was previously demonstrated to contain a number of pro- 
TABLE I. Effect of CBE on DUI45 Cell Number ${ }^{\dagger}$

\begin{tabular}{lccl}
\hline Conditions & Day 1 & Day 2 & Day 4 \\
\hline $10 \%$ serum & $7.48 \pm 0.38$ & $14.33 \pm 2.35$ & $77.96 \pm 3.63$ \\
$2 \%$ serum & $7.54 \pm 0.41$ & $15.02 \pm 0.87$ & $67.79 \pm 1.96^{*}$ \\
$2 \%$ serum/CBE & $7.66 \pm 0.61$ & $14.34 \pm 1.33$ & $48.72 \pm 4.94^{* *}$ \\
\hline
\end{tabular}

${ }^{+}$DU145 cells $(5,000 /$ plate) were incubated overnight in media with $10 \%$ FBS. On day 0 , cells were then grown under the following conditions: $10 \%$ FBS, $2 \%$ FBS, or $2 \%$ FBS plus $20 \mu \mathrm{g} / \mathrm{ml}$ crude bone extract (CBE). Plates were rinsed and cells removed with trypsin/EDTA for Coulter counter measurement of cell number on days 1,2 , and 4 . Data are expressed as cell number $\left(\times 10^{3}\right) \pm$ SD of triplicate plates.

*Statistically significant when compared to $10 \%$ serum $(P<0.05)$.

**Statistically significant when compared to $2 \%$ serum $(P<0.05)$.

teins, including fibronectin, bone salioprotein (BSP), osteopontin (OPN), type I collagen, TGF $\beta$, IGF, PDGF, and several bone morphogenic proteins [11,12]. Fibronectin is known to support adhesion of a variety of cells and indeed in the current study was utilized as a positive control for attachment. However, fibronectin is not solely responsible for the level of DU145 cell attachment observed with $\mathrm{CBE}$, as an antibody to FN resulted in only a $38 \%$ reduction in CBE-mediated attachment of DU145 cells. Importantly, the concentration of antibody appeared to be appropriate for blocking FN-mediated attachment, as this antibody nearly abolished cell attachment in the FN-coated wells. Other bone-associated proteins that may account for the majority of the attachment activity of DU145 cells include the RGD sequence, containing proteins OPN and BSP. Several studies demonstrate that BSP and OPN mediate cell attachment in an RGD-dependent fashion [14,17-19].

In the present study, RGD peptides dramatically inhibited cell attachment to CBE-coated dishes. This result suggests that the peptides compete with RGD sequences present in proteins within $\mathrm{CBE}$, e.g., BSP and OPN, for binding to receptors on DU145 cells. RGD peptides also significantly reduced fibronectinmediated attachment, but to a lesser extent than RGD blockade of CBE-mediated attachment ( $27 \%$ for FN vs. $98 \%$ for CBE). The modest effect of RGD peptides on fibronectin-mediated attachment is in agreement with several other studies, and suggests that attachment of DU145 cells to fibronectin can occur via non-RGD motifs [20-22].

In order to provide further evidence that the boneassociated proteins, BSP and OPN, are involved in CBE-mediated attachment, the role of a cell surface receptor known to bind to BSP and OPN, the integrin $\alpha v \beta 3$ [19], was evaluated. DU145 cells were found to express mRNA for both $\alpha \mathrm{V}$ and $\beta 3$. This result supports the findings of Witkowski et al. [23], which demonstrated cell surface expression of $\alpha \mathrm{V}$ and $\beta 3$ on DU145 cells with FACS analysis. To address the contribution of $\alpha \mathrm{v} \beta 3$ in adhesion of cells to CBE-coated dishes, a blocking antibody to $\alpha v \beta 3$ (LM609) [24] was utilized. LM609 dramatically reduced CBE-mediated cell adhesion, while this antibody did not alter fibronectin-mediated attachment. Collectively, these results suggest that RGD-containing bone proteins, in addition to fibronectin, are major mediators in the attachment of DU145 cells to CBE.

The observed delay in attachment of DU145 cells to the CBE-coated wells, when compared to fibronectincoated wells, suggests that CBE stimulates the synthesis and/or transport of cell surface receptors from intracellular compartments to the plasma membrane. This hypothesis is supported by the results in which the protein synthesis inhibitor, cycloheximide, nearly eliminated cell adhesion in CBE-coated wells, while substantial cell adhesion was still observed in fibronectin-coated wells. Although the cycloheximide results indicate that protein synthesis is required, further studies are needed to delineate the precise mechanism(s) involved in CBE-mediated attachment of DU145 cells.

The spreading of prostate tumor cells on bone proteins observed in this study extends the results of Haq et al. [3], who demonstrated that prostate tumor cells preferentially adhered to bone marrow-derived endothelial cells. Data from the present study suggest that following diapedesis, prostate tumor cells can then directly adhere to the surrounding trabecular bone. Adhesion of cells to extracellular matrix proteins is recognized as influencing several fundamental aspects of cell function, including survival and differentiation [25]. Although tumor cell adhesion to sinusoidal endothelium is likely important in initiating secondary tumors in bone, the role of adhesion to bone matrix proteins for tumor growth is less clear. The mineralized compartment of bone contains a wide variety of growth factors which may facilitate the survival of tumor cells in the absence of adhesion [26]. In addition, hematopoietic and bone cells may secrete a variety of factors which promote tumor cell growth. Indeed, factors produced by bone fibroblasts [4], osteoblast-like cells [5], and factors present in bone marrow [27] have been demonstrated to enhance prostate tumor cell proliferation. Although the importance of tumor cell adhesion in the extravascular space of bone for tumor growth is not certain, we propose that through direct attachment to bone or adjacent extracellular matrix, tumor cells may have a greater impact on bone homeostasis due to an increase in proximity to bone cells and/or through receptor binding signal- 
ing processes. Receptor-mediated events may enhance the release of factors by tumor cells that act in a paracrine fashion to alter the dynamics of bone cells.

In contrast to the attachment findings, results indicate that bone protein extract and OPN are not chemotactic for DU145 cells. These findings were surprising, given that products from resorbing bone and OPN alone have been demonstrated to promote migration of breast cancer cells $[17,28]$. In addition, the $\alpha \mathrm{v} \beta 3$ integrin, which is expressed by DU145 cells, correlated with migration toward OPN in vascular smooth muscle cells [29]. These observations suggest that, unlike vascular smooth muscle cells, the expression of $\alpha v \beta 3$ by DU145 cells is not correlated with migration toward OPN. The lack of a chemotactic response by DU145 cells toward bone proteins observed in this study may not be reflective of chemotactic responses in all prostate cancer cells. However, this result does suggest that this particular cell line lacks appropriate receptors and/or signaling components to trigger migration in response to bone proteins. Alternatively, the bone protein extract utilized in this study may contain both pro- and antimigration factors, with the antimigration factors predominating. Although other promigration factors may be present in the bone extract, such as FN, OPN is not a promigration factor for DU145 cells.

Given the level of growth factors present in bone matrix, a reduction in cell number by CBE was surprising. These results may relate to the findings of Story et al. [30], who demonstrated that picomolar concentrations of transforming growth factor betas (TGF $\beta$ s) have antiproliferative activity in normal and hyperplastic prostate cells. Findings by Webber et al. [31], in which TGF $\beta$ was demonstrated to inhibit growth of DU145 cells, also implicate TGF $\beta$ in the antiproliferative effect of CBE on DU145 cell proliferation. TGFs are stored at high concentrations in bone matrix [26] and thus may provide sufficient antiproliferative signals to counteract the known mitogenic stimulus of other growth factors present in bone [6]. However, the pathogenesis of human prostate cancer indicates that prostate tumor cells proliferate in bone. The complexities of the proliferative response by tumor cells in the bone/bone marrow environment are yet to be elucidated, but may provide valuable insight for the development of potential therapeutic strategies for reducing the growth rate of prostate cancer cells in bone.

In conclusion, the results obtained in this study indicate that proteins present in mineralized bone promote the attachment of a human prostate cancer cell line in vitro. These results suggest that bone proteins play a key role in vivo during the development of metastatic prostate lesions in bone. Although we are beginning to gain some insight into the mechanisms of preferential metastasis of prostate cancer cells to bone, further investigation is needed to elucidate the mechanism(s) involved in the disruption of bone homeostasis.

\section{ACKNOWLEDGMENTS}

We thank Mary Schmidt for the preparation of this manuscript.

\section{REFERENCES}

1. Waltregny D, Castronovo V: Recent advances in prostate cancer metastasis. Tumori 1996;82:193-204.

2. Chiarodo A: National Cancer Institute Roundtable on Prostate Cancer: Future research directions. Cancer Res 1991;51:24982505.

3. Haq M, Goltzman D, Tremblay G, Brodt P: Rat prostate adenocarcinoma cells disseminate to bone and adhere preferentially to bone marrow-derived endothelial cells. Cancer Res 1992;52: 4613-4619.

4. Gleave M, Hsieh J-T, Gao C, von Eschenbach AC, Chung LWK: Acceleration of human prostate cancer growth in vivo by factors produced by prostate and bone fibroblasts. Cancer Res 1991;51: 3753-3761.

5. Lang SH, Miller WR, Habib FK: Stimulation of human prostate cancer cell lines by factors present in human osteoblast-like cells but not in bone marrow. Prostate 1995;27:287-293.

6. Iwamura M, Sluss PM, Casamento JB, Cockett ATK: Insulin-like growth factor I: Action and receptor characterization in human prostate cancer cell lines. Prostate 1993;22:243-252.

7. Ritchie CK, Andrews LR, Thomas KG, Tindall DJ, Fitzpatrick LA: The effects of growth factors associated with osteoblasts on prostate carcinoma proliferation and chemotaxis: Implications for the development of metastatic disease. Endocrinology 1997; 138:1145-1150.

8. Bilezikian JP, Raisz LG, Rodan GA: "Principles of Bone Biology," San Diego, Academic Press, 1996:1355.

9. Stone KR, Mickey DD, Wunderli H, Mickey GH, Paulson DF: Isolation of a human prostate carcinoma cell line (DU145). Int J Cancer 1978;21:274-281.

10. Horoszewicz JS, Leong SS, Chu TM, Wajsman ZL, Friedman M, Papsidero L, Kim U, Chai LS, Kakati S, Arya SK, Sandberg AA: The LNCaP cell line-A new model for studies on human prostatic carcinoma. Prog Clin Biol Res 1980;37:115-132.

11. Shigeyama Y, D'Errico JA, Stone R, Somerman MJ: Commercially-prepared allograft material has biological activity in vitro. J Periodontol 1995;66:478-487.

12. Fisher LW, Hawkins GR, Tuross N, Termine JD: Purification and partial characterization of small proteoglycans I and II, bone sialoproteins I and II, and osteonectin from the mineral compartment of developing human bone. J Biol Chem 1987;262: 9702-9708.

13. Xie WQ, Rothblum LI: Rapid, small-scale RNA isolation from tissue culture cells. Biotechniques 1991;11:324,326-327.

14. Xuan J-W, Hota C, Chambers AF: Recombinant GST-human osteopontin fusion protein is functional in RGD-dependent cell adhesion. J Cell Biochem 1994;54:247-255.

15. Somerman MJ, Fisher LW, Foster RA, Sauk JJ: Human bone sialoprotein I and II enhance fibroblast attachment in vitro. Calcif Tissue Int 1988;43:50-53.

16. Hauschka PV, Wians FH: Ostoecalcin-hydroxyapatite interac- 
tion in the extracellular organic matrix of bone. Anat Rec 1989; 224:180-188.

17. Xuan J-W, Hota C, Shigeyama Y, D'Errico JA, Somerman MJ, Chambers AF: Site-directed mutagenesis of the arginineglycine-aspartic acid sequence in osteopontin destroys cell adhesion and migration functions. J Cell Biochem 1995;57:680-690.

18. Chambers AF, Hota C, Prince CW: Adhesion of metastatic, rastransformed NIH $3 \mathrm{~T} 3$ cells to osteopontin, fibronectin, and laminin. Cancer Res 1993;53:701-706.

19. Miyauchi A, Alvarez J, Greenfield EM, Teti A, Grano M, Colucci S, Zambonin-Zallone A, Ross FP, Teitelbaum SL, Cheresh D, Hruska KA: Recognition of osteopontin and related peptides by an $\alpha_{v} \beta_{3}$ integrin stimulates immediate cell signals in osteoclasts. J Biol Chem 1991;266:20369-20374.

20. Castoldi M, Pistone M, Caruso C, Puddu A, Filanti C, Piccini D, Tacchetti C, Manduca P: Osteoblastic cells from rat long bone. II: Adhesion to substrata and integrin expression in primary and propagated cultures. Cell Biol Int 1997;21:7-16.

21. Grzesik WJ, Robey PG: Bone matrix RGD glycoproteins: Immunolocalization and interaction with human primary osteoblastic bone cells in vitro. J Bone Miner Res 1994;9:487-496.

22. Pistone M, Sanguineti C, Federici A, Sanguineti F, Defilippi P, Santolini F, Querze G, Marchisio PC, Manduca P: Integrin synthesis and utilization in cultured human osteoblasts. Cell Biol Int 1996;20:471-479.

23. Witkowski CM, Rabinovitz I, Nagle RB, Affinito KS, Cress AE: Characterization of integrin subunits, cellular adhesion and tumorgenicity of four human prostate cell lines. J Cancer Res Clin Oncol 1993;119:637-644.
24. Cheresh DA, Spiro RC: Biosynthetic and functional properties of an Arg-Gly-Asp-directed receptor involved in human melanoma cell attachment to vitronectin, fibrinogen, and von Willebrand factor. J Biol Chem 1987;262:17703-17711.

25. Meredith JE, Winitz S, Lewis JM, Hess S, Ren X-D, Renshaw MW, Schwartz MA: The regulation of growth and intracellular signaling by integrins. Endocr Rev 1996;17:207-220.

26. Yoneda T, Sasaki A, Mundy GR: Osteolytic bone metastasis in breast cancer. Breast Cancer Res Treat 1994;32:73-84.

27. Chackal-Roy M, Niemeyer C, Moore M, Zetter BR: Stimulation of human prostatic carcinoma cell growth by factors present in human bone marrow. J Clin Invest 1989;84:43-50.

28. Orr W, Varani J, Gondek MD, Ward PA, Mundy GR: Chemotactic responses of tumor cells to products of resorbing bone. Science 1979;203:176-179.

29. Liaw L, Skinner MP, Raines EW, Ross R, Cheresh DA, Schwartz SM, Giachelli CM: The adhesive and migratory effects of osteopontin are mediated via distinct cell surface integrins. Role of alpha $\mathrm{v}$ beta 3 in smooth muscle cell migration to osteopontin in vitro. J Clin Invest 1995;95:713-724.

30. Story MT, Hopp KA, Molter M: Expression of transforming growth factor beta 1 (TGF $\beta 1$ ), $-\beta 2$, and $-\beta 3$ by cultured human prostate cells. J Cell Physiol 1996;169:97-107.

31. Webber MM, Bello D, Quader S: Immortalized and tumorigenic adult human prostatic epithelial cell lines: Characteristics and applications part 2. Tumorigenic cell lines. Prostate 1997; 30:58-64. 